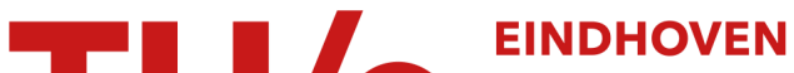 \\ UNIVERSITY OF \\ TECHNOLOGY
}

\section{Hexanuclear iridium clusters supported on magnesium oxide}

Citation for published version (APA):

Maloney, S. D., Kelley, M. J., Koningsberger, D. C., \& Gates, B. C. (1991). Hexanuclear iridium clusters supported on magnesium oxide. Journal of Physical Chemistry, 95(23), 9406-9411.

https://doi.org/10.1021/j100176a068

DOI:

10.1021/j100176a068

Document status and date:

Published: 01/01/1991

\section{Document Version:}

Publisher's PDF, also known as Version of Record (includes final page, issue and volume numbers)

\section{Please check the document version of this publication:}

- A submitted manuscript is the version of the article upon submission and before peer-review. There can be important differences between the submitted version and the official published version of record. People interested in the research are advised to contact the author for the final version of the publication, or visit the $\mathrm{DOI}$ to the publisher's website.

- The final author version and the galley proof are versions of the publication after peer review.

- The final published version features the final layout of the paper including the volume, issue and page numbers.

Link to publication

\section{General rights}

Copyright and moral rights for the publications made accessible in the public portal are retained by the authors and/or other copyright owners and it is a condition of accessing publications that users recognise and abide by the legal requirements associated with these rights.

- Users may download and print one copy of any publication from the public portal for the purpose of private study or research.

- You may not further distribute the material or use it for any profit-making activity or commercial gain

- You may freely distribute the URL identifying the publication in the public portal.

If the publication is distributed under the terms of Article 25fa of the Dutch Copyright Act, indicated by the "Taverne" license above, please follow below link for the End User Agreement:

www.tue.nl/taverne

Take down policy

If you believe that this document breaches copyright please contact us at:

openaccess@tue.nl

providing details and we will investigate your claim. 


\title{
Hexanuclear Iridlum Clusters Supported on Magnesium Oxide
}

\author{
S. D. Maloney, ${ }^{\dagger}$ M. J. Kelley, ${ }^{\ddagger}$ D. C. Koningsberger, ${ }^{\S}$ and B. C. Gates ${ }^{* \dagger}$ \\ Center for Catalytic Science and Technology, Department of Chemical Engineering, University of Delaware, \\ Newark, Delaware 19716, Engineering Technology Laboratory, Experimental Station, E. I. du Pont de \\ Nemours and Company, Wilmington, Delaware 19898, and Laboratory for Inorganic Chemistry and Catalysis, \\ Eindhoven University of Technology, P.O. Box 513,5600 MB Eindhoven, The Netherlands \\ (Received: November 19, 1990; In Final Form: July 22, 1991)
}

$\left[\mathrm{Ir}_{4}(\mathrm{CO})_{12}\right]$ on the surface of $\mathrm{MgO}$ reacts to give $\left[\mathrm{HIr}_{4}(\mathrm{CO})_{11}\right]^{-}$, which upon treatment with $\mathrm{CO}$ at $200^{\circ} \mathrm{C}$ gives $\left[\mathrm{Ir}_{6}(\mathrm{CO})_{15}\right]^{2-}$ on the surface in high yield. Treatment of the latter with a solution of $[\mathrm{PPN}][\mathrm{Cl}]$ leads to extraction of $\left[\mathrm{Ir}_{6}(\mathrm{CO})_{15}\right]^{2-}$ by cation metathesis. The surface-bound $\left[\operatorname{Ir}_{6}(\mathrm{CO})_{15}\right]^{2-}$ was characterized by extended $\mathrm{X}$-ray absorption fine structure (EXAFS) spectroscopy, with the data indicating an average Ir-Ir coordination number of 4.1 and an average Ir-Ir distance of 2.77 $\AA$, in close agreement with the published crystallographic data for this anion in the solid state. The reactions of the iridium carbonyls on the basic $\mathrm{MgO}$ surface closely parallel those of iridium carbonyl anions in basic solutions. Treatment of the $\mathrm{MgO}$-supported $\left[\mathrm{Ir}_{6}(\mathrm{CO})_{15}\right]^{2-}$ in $\mathrm{He}$ followed by $\mathrm{H}_{2}$ at $300^{\circ} \mathrm{C}$ gives decarbonylated surface species shown by EXAFS spectroscopy to have iridium cluster frames substantially unchanged from those of the carbonyl anion precursor. The decarbonylated iridium clusters are among the most nearly uniform supported metals.

\section{Introduction}

The crucial structural elements in numerous modern materials are microstructures dispersed on surfaces of supports (substrates); the microstructures range from metals in supported catalysts to semiconductors in electronic devices. Understanding of the chemistry and function of these materials will be advanced by the development of methods for synthesis and characterization of discrete, structurally uniform microstructures on supports. ${ }^{1}$ Organometallic clusters have been used frequently in attempts to prepare uniform metal structures on supports, but the attempts have been largely unsuccessful since decarbonylation of the clusters has almost always given fragmented and/or aggregated clusters. ${ }^{2}$ Initial indications of success have recently been communicated, however, with robust metal cluster carbonyls inferred to have given nearly uniform $\mathrm{Os}_{10}{ }^{3}$ and $\mathrm{Ir}_{4}{ }^{4}$ on $\mathrm{MgO}$.

The goal of this research was to investigate the surface chemistry of iridium carbonyl clusters in attempts to prepare robust and structurally unique species that can serve as precursors of structurally unique decarbonylated metal clusters. Infrared and extended X-ray absorption fine structure (EXAFS) spectroscopies were used to characterize the surface species.

\section{Results}

Formation of $\left[\mathrm{Ir}_{6}(\mathrm{CO})_{15}\right]^{2-} / \mathrm{MgO}$ and Characterization by Extraction and Infrared Spectroscopy. When $\left[\mathrm{Ir}_{4}(\mathrm{CO})_{12}\right]$ was brought in contact with partially hydroxylated $\mathrm{MgO}$, a chemisorbed iridium carbonyl was formed, inferred on the basis of infrared and EXAFS spectroscopies to be $\left[\mathrm{HIr}_{4}(\mathrm{CO})_{11}\right]^{-}$; this anion could be removed from the surface by extraction with [PPN] $[\mathrm{Cl}]$ in THF. ${ }^{4}$ Treatment of the sample formulated as $\left[\mathrm{HIr}_{4}(\mathrm{CO})_{11}\right]^{-} / \mathrm{MgO}$ with $\mathrm{CO}$ at temperatures greater than 100 ${ }^{\circ} \mathrm{C}$ led to changes in the infrared spectrum (Figure 1). The spectrum characteristic of the supported tetrairidium carbonyl anion disappeared as the temperature was raised to $200^{\circ} \mathrm{C}$, and a nearly symmetric peak appeared in the carbonyl stretching region. The spectrum remained unchanged when the sample was held in the infrared cell at $200^{\circ} \mathrm{C}$ for $2 \mathrm{~h}$. Upon further treatment at higher temperatures, the peak intensity decreased, indicating decomposition of the supported iridium carbonyl.

A sample prepared from [ $\mathrm{Ir}_{4}(\mathrm{CO})_{12}$ ] and $\mathrm{MgO}$ heated to 200 ${ }^{\circ} \mathrm{C}$ in $\mathrm{CO}$, a brown powder, was loaded into an infrared cell and sealed under a positive pressure of $\mathrm{N}_{2}$. The spectrum, recorded at room temperature, is shown in Figure 1B. The cell was unloaded under $\mathrm{N}_{2}$ in the drybox and the sample brought in contact

\footnotetext{
* Address correspondence to this author.

+ University of Delaware.

E. I. du Pont de Nemours and Co.

Eindhoven University of Technology.
}

with excess [PPN] $[\mathrm{Cl}]$ in THF. The brown extract solution had an infrared spectrum (Figure $1 \mathrm{C}$ ) similar to that of $\left[\mathrm{Ir}_{6}(\mathrm{CO})_{15}\right]^{2-}$ (Figure 1D) mixed with $\left[\operatorname{Ir}(\mathrm{CO})_{4}\right]^{-}$.

After filtration, $\left[\mathrm{Ir}_{4}(\mathrm{CO})_{12}\right]$ was added to the solution, with stirring under $\mathrm{CO}$ at $60^{\circ} \mathrm{C}$. The $\left[\mathrm{Ir}_{4}(\mathrm{CO})_{12}\right]$ reacted with the $\left[\operatorname{Ir}(\mathrm{CO})_{4}\right]^{-}$to give $\left[\operatorname{Ir}_{6}(\mathrm{CO})_{15}\right]^{2-} ;$ the consumption of $\left[\operatorname{Ir}(\mathrm{CO})_{4}\right]^{-}$ was monitored by the disappearance of the $1895-\mathrm{cm}^{-1}$ band in the infrared spectrum. After the disappearance of this peak, the spectrum showed strong bands at 1993 and $1984 \mathrm{~cm}^{-1}$, characteristic of $\left[\operatorname{Ir}_{6}(\mathrm{CO})_{15}\right]^{2-}$.

The brown $\left[\mathrm{Ir}_{6}(\mathrm{CO})_{15}\right]^{2-}$ has been observed by Angoletta et al. ${ }^{5}$ as a product of the reaction of $\left[\mathrm{Ir}_{4}(\mathrm{CO})_{12}\right]$ with $\mathrm{Na}$ in THF. ${ }^{6}$ To be more confident of the spectrum of $\left[\mathrm{Ir}_{6}(\mathrm{CO})_{15}\right]^{2-}$ in solution, we repeated its preparation from $\left[\mathrm{Ir}_{4}(\mathrm{CO})_{12}\right]$ with $\mathrm{Na}$ in THF by the method of Stevens et al. ${ }^{7}$ In agreement with the observations of Stevens, the reaction proceeded with the spectrum indicating only two predominant species, $\left[\operatorname{Ir}_{6}(\mathrm{CO})_{15}\right]^{2-}$ and a product of its reaction in the presence of $\mathrm{Na},\left[\operatorname{Ir}(\mathrm{CO})_{4}\right]^{-}$, as shown by a band at $1984 \mathrm{~cm}^{-1}$, indicative of the former, and a strong band at $1895 \mathrm{~cm}^{-1}$, indicative of the latter. In contrast to the published spectrum of Stevens et al., ${ }^{7 \mathrm{a}}$ another band, at $1991 \mathrm{~cm}^{-1}$, was observed to grow in proportion to the $1984-\mathrm{cm}^{-1}$ band. However, a splitting into two bands, at about 1995 and $1985 \mathrm{~cm}^{-1}$, was observed by Stevens et al. ${ }^{7 b}$ as the $\left[\operatorname{Ir}_{6}(\mathrm{CO})_{15}\right]^{2-}$ was formed in the presence of $\mathrm{Na}$, in agreement with the results of this work.

These two strong bands are inferred to indicate the hexairidium cluster anion. The data of Table I indicate that the cation exerts a significant influence on the spectrum, and the data for the $\mathrm{Na}^{+}$ and $\mathrm{PPN}^{+}$salts indicate that the presence of the $1991-\mathrm{cm}^{-1}$ band

(1) Andres, R. P.; Averback, R. S.; Brown, W. L.; Brus, L. E.; Goddard, W. A., III; Kaldor, A.; Louie, S. G.; Moscovits, M.; Peercy, P. S.; Riley, S J.; Siegel, R. W.; Spaepen, F.; Wang, Y. J. Mater, Res. 1989, 4, 704.

(2) Gates, B. C.; Guczi, L.; Knözinger, H. Metal Clusters in Catalysis; Elsevier: Amsterdam, 1986.

(3) Lamb, H. H.; Wolfer, M.; Gates, B. C. J. Chem. Soc., Chem. Commun. 1990, 1296.

(4) Maloney, S. D.; van Zon, F. B. M.; Kelley, M. J.; Koningsberger, D. C.; Gates, B. C. Catal. Lett. 1990, 5, 161. 94,99

5) Angoletta, M.; Malatesta, L.; Caglio, G. J. Organomet. Chem. 1975,

(6) The formation of the hexairidium cluster anion was indicated by the appearance of a peak at $1980 \mathrm{~cm}^{-1}$, reported by Angoletta et al. ${ }^{5}$ However, these authors reported the strong band at 1970 rather than $1980 \mathrm{~cm}^{-1}$ for $\left[\mathrm{NEt}_{4}\right]_{2}\left[\mathrm{Ir}_{6}(\mathrm{CO})_{15}\right]$. The hexairidium cluster anion continued to react with the sodium to form $\left[\operatorname{Ir}(\mathrm{CO})_{4}\right]^{-}$, which was identified by a characteristic strong band at $1985 \mathrm{~cm}^{-1}$. Stevens et al, ${ }^{7}$ reported an improved synthesis of the anionic hexairidium cluster, whereby $\left[\mathrm{Ir}_{4}(\mathrm{CO})_{12}\right]$ reacts with $\mathrm{Na}$ sand in $\mathrm{THF}$ under $\mathrm{CO}$ until the infrared spectrum of the solution indicates only two species, $\left[1 r_{6}(\mathrm{CO})_{15}\right]^{2-}$ and $\left[\operatorname{Ir}(\mathrm{CO})_{4}\right]^{-}$. These authors did not report the locations of all the bands in the infrared spectra attributed to these two anions, but they did attribute a band at $1983 \mathrm{~cm}^{-1}$ to $\left[\mathrm{Ir}_{6}(\mathrm{CO})_{15}\right]^{2-}$.

(7) (a) Stevens, R. E.; Lin, P. C. C.; Gladfelter, W. L. J. Organomet. Chem. 1985, 287, 133. (b) Gladfelter, W. L., personal communication, 1991. 
TABLE I: Infrared Spectra in the Carbonyl Stretching Region of $\mathrm{MgO}_{\mathbf{g}} \mathrm{-Supported} \mathrm{Species} \mathrm{Formed} \mathrm{from}\left[\mathrm{Ir}_{4}(\mathrm{CO})_{12}\right]$ and Related Molecular Clusters

\begin{tabular}{|c|c|c|}
\hline sample & $\nu_{\mathrm{CO}}, \mathrm{cm}^{-1}$ & ref \\
\hline $\begin{array}{l}\mathrm{MgO} \text {-supported sample prepared from } \\
{\left[\mathrm{Ir}_{4}(\mathrm{CO})_{12}\right]}\end{array}$ & $2056(w), 2008(s), 1831(w)$ & this work \\
\hline $\begin{array}{l}{[\mathrm{PPN}][\mathrm{Cl}] \text { extract from above sample }} \\
{[\mathrm{PPN}]_{2}\left[\left[\mathrm{Ir}_{6}(\mathrm{CO})_{15}\right] \text { prepared by method of }\right.}\end{array}$ & $\begin{array}{l}1987(\mathrm{~s}), 1979(\mathrm{~s}), 1771(\mathrm{~m}), 1716(\mathrm{w}) \\
2068(\mathrm{w}), 2017(\mathrm{~m}), 1993(\mathrm{~s}), 1984(\mathrm{~s}), 1928(\mathrm{vw}), 1823(\mathrm{vw}),\end{array}$ & $\begin{array}{l}\text { this work } \\
\text { this work }\end{array}$ \\
\hline $\begin{array}{l}{\left[\mathrm{Na}_{2}\left[\left[\mathrm{Ir}_{6}(\mathrm{CO})_{15}\right]\right.\right.} \\
{\left[\mathrm{NMe}_{4}\right]_{2}\left[\mathrm{Ir} \mathrm{r}_{6}(\mathrm{CO})_{1 \mathrm{~s}}\right]}\end{array}$ & $\begin{array}{l}1993(\mathrm{~s}), 1984(\mathrm{~s}), 1928(\mathrm{w}), 1788(\mathrm{~m}), 1735(\mathrm{~m}) \\
2030(\mathrm{sh}), 1970(\mathrm{~s}), 1910(\mathrm{sh}), 1775(\mathrm{~s}), 1735(\mathrm{~s})\end{array}$ & $\begin{array}{l}\text { this work } \\
5\end{array}$ \\
\hline
\end{tabular}

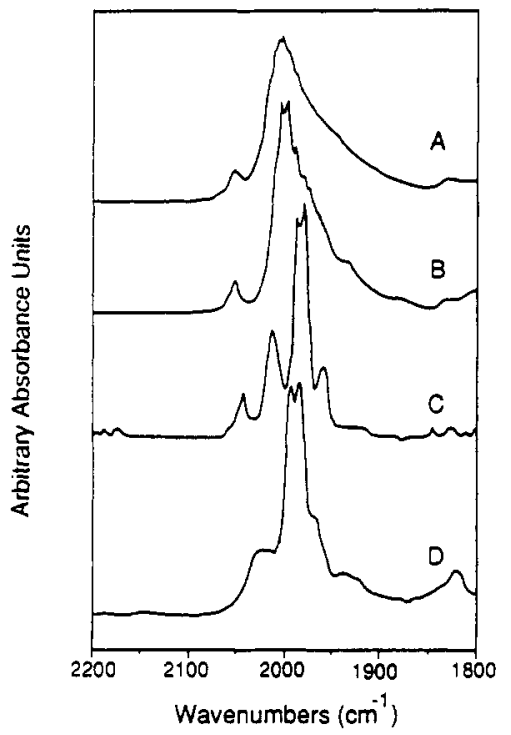

Figure 1. Infrared spectra of $\left[\mathrm{Ir}_{6}(\mathrm{CO})_{15}\right]^{2-}$ and the sample prepared by adsorption of $\left[\mathrm{Ir}_{4}(\mathrm{CO})_{12}\right]$ on $\mathrm{MgO}$ followed by treatment in $\mathrm{CO}$. (A) DRIFTS of sample prepared by adsorption of $\left[\mathrm{Ir}_{4}(\mathrm{CO})_{12}\right]$ on $\mathrm{MgO}$ followed by treatment with $\mathrm{CO}$ at 1 atm and $200^{\circ} \mathrm{C}$ for $1 / 2 \mathrm{~h}$; (B) DRIFTS of sample treated in CO at $15 \mathrm{~atm}$ and $200^{\circ} \mathrm{C}$ for $2 \mathrm{~h}$ in a flow reactor; (C) spectrum of the extract solution formed from bringing the sample of spectrum B in contact with [PPN][Cl] in THF; (D) spectrum of $[\mathrm{Na}]_{2}\left[\mathrm{Ir}_{6}(\mathrm{CO})_{15}\right]$ in THF solution.

(among others) in the latter may be attributed to strongly ionpaired $\left[\mathrm{Ir}_{6}(\mathrm{CO})_{15}\right]^{2-}$ associated with $\mathrm{Na}^{+}$retained from the synthesis in the presence of $\mathrm{Na}$ and in agreement with the results of Stevens et al. ${ }^{7 b}$ The spectrum also indicates the presence of some residual tetranuclear species, $\left[\mathrm{Ir}_{4}(\mathrm{CO})_{12}\right]$ and $\left[\mathrm{HIr}_{4}(\mathrm{CO})_{11}\right]^{-}$, as shown by small peaks at 2068 and $2017 \mathrm{~cm}^{-1}$, respectively. This spectrum is similar to that characteristic of the $[\mathrm{PPN}][\mathrm{Cl}] / \mathrm{THF}$ extract solution prepared from the MgO-supported iridium carbonyl that had been treated with $\mathrm{CO}$ at $200^{\circ} \mathrm{C}$.

The spectrum of the $\mathrm{Na}^{+}$salt of $\left[\mathrm{Ir}_{6}(\mathrm{CO})_{1 \mathrm{~s}}\right]^{2-}$ shown in Figure $1 D$ has a peak at about $1825 \mathrm{~cm}^{-1}$; this peak was not present in every spectrum characterizing this sample, and it is attributed to an unidentified impurity.

In summary, the present results are judged to be consistent with the reports of Stevens et al. ${ }^{7}$ and Angoletta et al., ${ }^{5}$ and the differences in the several spectra that are attributed to $\left[\mathrm{Ir}_{6}(\mathrm{CO})_{15}\right]^{2-}$ reflect different ion-pairing effects.

The spectrum of the surface-bound iridium carbonyl species (Figure 1) is similar to that of $\left[\operatorname{Ir}_{6}(\mathrm{CO})_{15}\right]^{2-}$ in solution but is shifted and broadened with respect to the solution spectrum, as is typical of metal carbonyls on solid supports. A peak attributed to unconverted tetrairidium species is also present, as in the solution spectrum (Table I).

All these results are consistent with the inference that $\left[\mathrm{Ir}_{6}\right.$ $\left.(\mathrm{CO})_{15}\right]^{2-}$ had formed on the $\mathrm{MgO}$ surface and was the predominant organometallic species, but they are not sufficient to define the surface structures. Extraction with [PPN] $[\mathrm{Cl}]$ evidently took place by simple cation metathesis, and the results of the extraction experiment are indicative of $\left[\mathrm{Ir}_{6}(\mathrm{CO})_{15}\right]^{2-}$ as the predominant surface species.

Characterization of $\left[\operatorname{Ir}_{6}(\mathrm{CO})_{15}\right]^{2-} / \mathbf{M g O}$ by EXAFS Spectroscopy. EXAFS spectra of the supported iridium carbonyl were measured to test the structural inferences based on infrared spectroscopy. The raw EXAFS data characterizing the sample prepared by adsorption of $\left[\mathrm{Ir}_{4}(\mathrm{CO})_{12}\right]$ on $\mathrm{MgO}$ followed by treatment with $\mathrm{CO}$ at $200{ }^{\circ} \mathrm{C}$ and inferred from the infrared spectra to incorporate $\left[\mathrm{Ir}_{6}(\mathrm{CO})_{15}\right]^{2-}$ are shown in Figure 2B. For comparison, the raw EXAFS data characterizing the sample prepared by adsorption of $\left[\mathrm{Ir}_{4}(\mathrm{CO})_{12}\right]$ on $\mathrm{MgO}$ to give the stable $\left[\mathrm{HIr}_{4}(\mathrm{CO})_{11}\right]^{-} / \mathrm{MgO}^{4}$ are shown in Figure $2 \mathrm{~A}$. In the intermediate $\left(8<k<11 \AA^{-1}\right)$ and higher ranges of the wave vector $k$, there are strong oscillations characteristic of the sample inferred to incorporate the hexairidium clusters. The intense oscillations at the higher values of $k$ are characteristic of metal-metal interactions, consistent with the presence of clusters, and the high frequency of these in comparison with those of $\left[\mathrm{HIr}_{4}(\mathrm{CO})_{11}\right]^{-}$ indicates the presence of $\mathrm{Ir}-\mathrm{Ir}$ bonds with greater bond distances than in $\left[\mathrm{HIr}_{4}(\mathrm{CO})_{11}\right]^{-}$.

The Koningsberger difference file technique ${ }^{8,9}$ was used to analyze the EXAFS data obtained for the sample treated with flowing $\mathrm{CO}$ at $1 \mathrm{~atm}$ and $200^{\circ} \mathrm{C}$ for $8 \mathrm{~h}$. The raw data were Fourier transformed with $k^{3}$ weighting in the range $2.77<k<$ $15.03 \AA^{-1}$. The first-shell contributions to the EXAFS were isolated by inverse Fourier transformation of the data over the range $1.08<R<3.04 \AA$, where $R$ is distance from the scattering atom (Ir). In agreement with the infrared spectrum, the EXAFS data show that there was predominantly one symmetrical metal carbonyl species present.

The isolated first-shell EXAFS data were fitted on the basis of reference files determined experimentally from EXAFS data for $\mathrm{Pt}$ foil (to represent the $\mathrm{Ir}-\mathrm{Ir}$ interactions) and $\left[\mathrm{Ir}_{4}(\mathrm{CO})_{12}\right]$ (to represent the $\mathrm{Ir}-\mathrm{CO}$ interactions). The procedure was started by fitting the isolated first-shell data over the higher $k$ range on the basis of the reference file for the Ir-Ir interactions. After this fit had been determined, an EXAFS function ( $\chi$ function) was calculated from the parameters that had been estimated and subtracted from the isolated first-shell data. If the estimate were a good first approximation, the residual function would consist predominantly of the contributions arising from the $\mathrm{I} r-\mathrm{C}$ and $\mathrm{I}-\mathrm{O}^{*}$ interactions, where $\mathrm{O}^{*}$ refers to the carbonyl oxygen. The next step was to fit the residual function with contributions on the basis of the reference file characterizing these interactions (the $\left[\mathrm{Ir}_{4}(\mathrm{CO})_{12}\right]$ file). Fitting the residual function with the two contributions ( $\mathrm{Ir}-\mathrm{C}$ and $\mathrm{Ir}-\mathrm{O}^{*}$ ) was not sufficient to represent the data in the region of approximately $2.1 \AA$. Therefore, in subsequent fitting, another contribution was included, representing a carbon atom of a bridging carbonyl ligand ( $\mathrm{I}-\mathrm{C}_{\mathrm{b}}$ ).

After estimation of the coordination parameters for the $\mathrm{Ir}-\mathrm{Ir}$ and $\mathrm{Ir}-\mathrm{CO}$ interactions, further fine-tuning of the fit was carried out with four contributions, $\mathrm{Ir}-\mathrm{C}_{\mathrm{t}}$ ( $\mathrm{t}$ refers to the terminal carbon), $\mathrm{Ir}-\mathrm{C}_{\mathrm{b}}, \mathrm{Ir}-\mathrm{O}^{*}$, and $\mathrm{Ir}-\mathrm{Ir}$, for the first-shell data. The parameters for one contribution were allowed to vary in the fitting routine while parameters for the other three contributions were held constant. Alternatively, the coordination numbers for all the contributions were allowed to vary while the remaining parameters were fixed. This iterative procedure was followed, in turn, by varying all the other parameters, namely, the Debye-Waller factors, distances, and inner potential corrections. The fitting

(8) Van Zon, T. B. A. D.; Koningsberger, D. C.; Van't Blik, H. F. J.; Sayers, D. E. J. Chem. Phys. 1985, 82, 5742

(9) Kampers, F. W. H. Thesis, Eindhoven University of Technology, The Netherlands, 1988. 

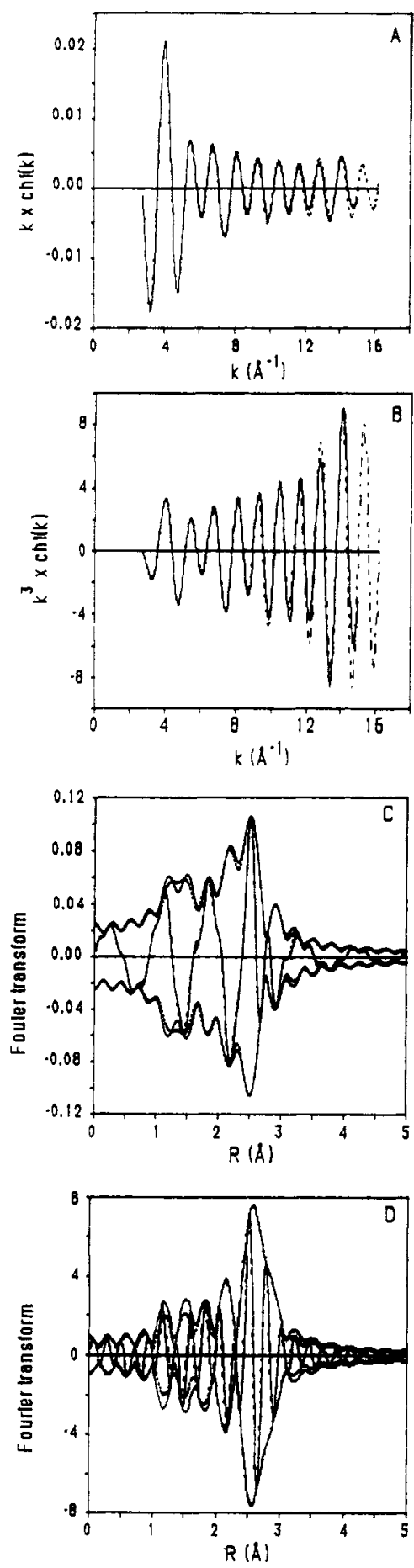

Figure 2. EXAFS spectra characterizing the sample prepared by adsorption of $\left[\mathrm{Ir}_{4}(\mathrm{CO})_{12}\right]$ on $\mathrm{MgO}$ followed by treatment with $\mathrm{CO}$ at $1 \mathrm{~atm}$ and $200^{\circ} \mathrm{C}$ for $2 \mathrm{~h}$. (A) Isolated first-shell data (-) and sum of the calculated $\mathrm{Ir}-\mathrm{Ir}, \mathrm{Ir}-\mathrm{C}_{\mathrm{t}}, \mathrm{Ir}-\mathrm{C}_{\mathrm{b}}$, and $\mathrm{Ir}-\mathrm{O}^{*}$ contributions $(\cdots), k^{1}$-weighted; (B) isolated first-shell data ( - ) and sum of the calculated Ir-Ir, Ir-C Ir $-\mathrm{C}_{b}$, and $\mathrm{I} r-\mathrm{O}^{*}$ contributions (-.-), $k^{3}$-weighted; (C) magnitude and imaginary parts of the Fourier transforms of the isolated first-shell ( - ) and sum of the calculated $\mathrm{Ir}-\mathrm{Ir}, \mathrm{Ir}-\mathrm{C}, \mathrm{Ir}-\mathrm{C}_{b}$, and $\mathrm{Ir}-\mathrm{O}^{*}$ contributions $(\cdots), k^{1}$-weighted; (D) magnitude and imaginary parts of the Fourier transforms of the isolated first shell ( - ) and sum of the calculated Ir-Ir, $\operatorname{Ir}-\mathrm{C}_{\mathrm{b}}, \mathrm{Ir}-\mathrm{C}_{\mathrm{t}}$, and $\mathrm{Ir}-\mathrm{O}^{*}$ contributions $(\cdots), k^{3}$-weighted.

procedure was performed repeatedly until further optimization resulted in minimal changes in the sum of the squares of the residuals between the isolated first-shell data and the calculated fit. The parameters determined in the final fit are shown in Table II; estimates of the experimental uncertainties in the parameters are shown in the table.

The results indicate an Ir-Ir coordination number of approximately 4 , consistent with the earlier inference that the predom-
TABLE II: Structural Parameters Determined by EXAFS Spectroscopy for the Sample Prepared from $\left[\mathrm{Ir}_{4}(\mathrm{CO})_{12}\right]$ on $\mathrm{MgO}$ Followed by Treatment with $\mathrm{CO}$ at $200^{\circ} \mathrm{C}$ for $8 \mathrm{~h}^{a}$

\begin{tabular}{cccccc}
\hline contribution & $N$ & $N_{\mathrm{adj}}$ & $R, \AA$ & $\Delta \sigma^{2}, \AA^{2}$ & $\Delta E_{0}, \mathrm{eV}$ \\
\hline $\mathrm{Ir}-\mathrm{C}_{\mathrm{t}}$ & 2.5 & 2.5 & 1.85 & 0.0042 & 0.59 \\
$\mathrm{Ir}-\mathrm{C}_{\mathrm{b}}$ & 1.4 & 1.5 & 2.13 & -0.0004 & -9.23 \\
$\mathrm{Ir}-\mathrm{Ir}_{\mathrm{r}}$ & 4.1 & 4.1 & 2.77 & 0.001 & 2.75 \\
$\mathrm{Ir}-\mathrm{O}^{*}$ & 1.3 & 1.3 & 3.05 & 0.0007 & -8.52
\end{tabular}

a Notation (approximate experimental uncertainty): $N$, coordination number $( \pm 20 \%) ; N_{\text {adj }}=N \exp \left[2\left(r_{i}-R_{\text {ref }}\right) / \lambda\right]$, where $\lambda$ is the electron mean free path, estimated to be $6 \AA ; R$, coordination distance $( \pm 0.02$ $\AA$ ); $\Delta \sigma^{2}$, Debye-Waller factor; $\Delta E_{0}$, inner potential correction.

inant surface species was a hexairidium carbonyl cluster. The average Ir-Ir distance is $2.77 \AA$.

There is a contribution from a terminal carbonyl carbon atom with a coordination number of approximately 2.5 at a distance of $1.85 \AA$. A contribution inferred to be a bridging carbon is indicated at a distance of $2.13 \AA$ with a coordination number of 1.5. A fourth contribution is identified as a terminal carbonyl oxygen present at a distance of $3.05 \AA$ with a coordination number of about 1.5 .

To verify that the fit was approximately equally good with respect to the low- $Z$ ( $C$ and $\mathrm{O}^{*}$ ) and high- $Z$ (metal) scatterers, the final fit was compared with the first-shell data with both $k^{1}$ and $k^{3}$ weighting (Figure 3 ). The $k^{1}$-weighted plot emphasizes the contributions of the low- $Z$ neighbors, and the $k^{3}$-weighted plot is dominated by the metal-metal interactions. The fit was checked in the Fourier transform as well as the $\chi$ plot. The fits of the individual contributions are shown in the phase-corrected Fourier transforms along with the Fourier transform of the residual $\chi$ plot after subtraction of all the other contributions (Figure 3 ). For example, to verify that the $I r-C_{t}$ contribution was fitted properly, the Fourier transform of the calculated EXAFS for this contribution was compared with the Fourier transform of the residual function obtained by subtracting the $\mathrm{I} r-\mathrm{Ir}, \mathrm{Ir}-\mathrm{C}_{\mathrm{b}}$, and $\mathrm{Ir}-\mathrm{O}^{*}$ contributions from the total. This comparison shows that the fit for the whole spectrum is a sum of contributions which are individually fitted well.

The number of adjustable coordination parameters which can be used in the fitting procedure to give statistically significant results is given approximately by the Nyquist theorem as $2 \Delta k \Delta R / \pi$, where $\Delta k$ and $\Delta R$ are the ranges of the forward and inverse Fourier transformations. For the data analysis presented here, this number is calculated to be $15.3\left(\Delta k=12.3 \AA^{-1}\right.$ and $\Delta R=1.96 \AA$ ), which is close to the total number of parameters (16) used in the fit. The goodness of the fit is shown by the comparisons of Figure 3.

Decarbonylation of $\left[\mathrm{Ir}_{6}(\mathrm{CO})_{15}\right]^{2-} / \mathbf{M g O}$. Qualitative temperature-programmed decomposition experiments indicated that the surface-bound iridium carbonyl is decarbonylated at approximately $300^{\circ} \mathrm{C}$. Consequently, the sample treated in $\mathrm{He}$ at this temperature was characterized by infrared spectroscopy; after $2 \mathrm{~h}$, only a very weak and broad carbonyl absorption remained, indicating that virtually all the $\mathrm{CO}$ ligands had been removed.

Since this decarbonylation could be expected to form hydrocarbon products in addition to $\mathrm{CO}$ and possibly $\mathrm{CO}_{2},{ }^{10}$ the sample was treated in $\mathrm{H}_{2}$ at $1 \mathrm{~atm}$ and $300^{\circ} \mathrm{C}$ for $2 \mathrm{~h}$ in an attempt to remove any hydrocarbons and leave the clean decarbonylated clusters on the support in the form of iridium hydrides. Since $\left[\mathrm{Ir}_{6}(\mathrm{CO})_{15}\right]^{2-}$ has a relatively stable metal frame, the goal of these treatments was to decarbonylate the cluster while leaving the metal frame intact and giving a structurally simple supported metal, $\mathrm{Ir}_{6}$.

To test whether this goal was achieved, the decarbonylated sample, in the presence of $\mathrm{H}_{2}$ at approximately liquid-nitrogen temperature, was characterized by EXAFS spectroscopy. The full EXAFS analysis, carried out by essentially the same method

(10) Smith, A. K.; Theolier, A.; Basset, J. M.; Ugo, R.; Commereuc, D.; Chauvin, Y.J. Am. Chem. Soc. 1978, 100, 2590. 

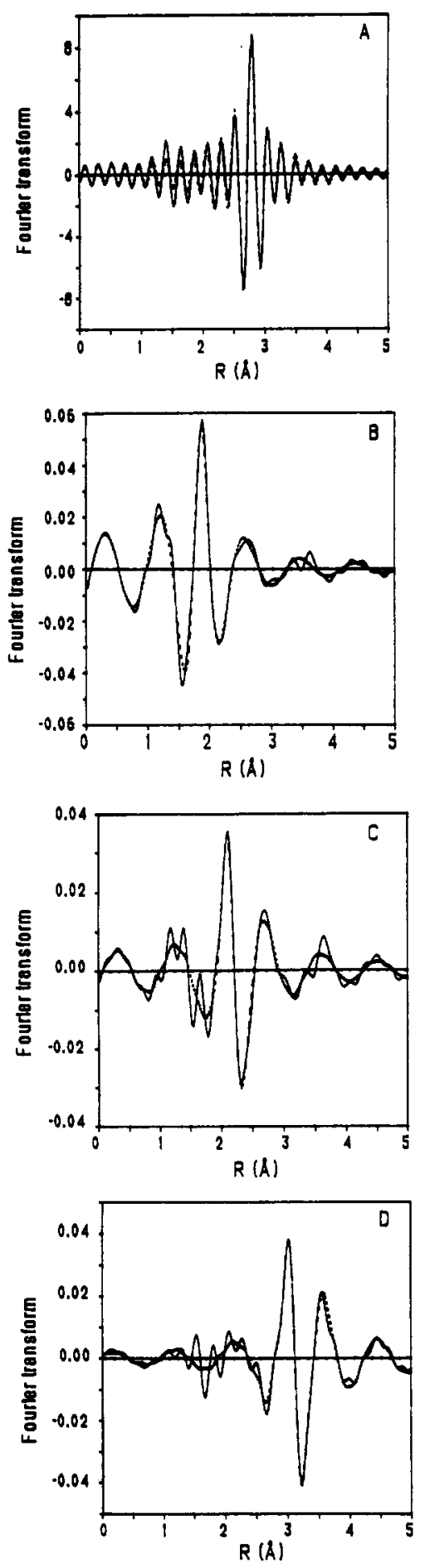

Figure 3. Imaginary parts of the Fourier transforms of the individual contributions to the EXAFS characterizing the sample prepared by adsorption of $\left[\mathrm{Ir}_{4}(\mathrm{CO})_{12}\right]$ on $\mathrm{MgO}$ followed by treatment with $\mathrm{CO}$ at 1 atm and $200^{\circ} \mathrm{C}$ for $2 \mathrm{~h}$. (A) Residual Ir-Ir contribution ( - ) and best fit $(--), k^{3}$-weighted and $\mathrm{Pt}-\mathrm{Pt}$ phase corrected; (B) residual $\mathrm{I} r-\mathrm{C}_{1}$ contribution (-) and best fit (-- $), k^{1}$-weighted and $\mathrm{Ir}-\mathrm{C}$ phase corrected; (C) residual I $r-C_{b}$ contribution ( - ) and best fit (-- ), $k^{1}$-weighted and Ir-C phase corrected; (D) residual Ir-O contribution (-) and best fit $(---), k^{1}$-weighted and $\mathrm{I} r-\mathrm{O}^{*}$ phase corrected.

described above, is complicated by the need to represent the metal-support interface to give a good fit; details will be reported elsewhere." The important result is that the cluster carbonyl ligands had been removed without much change in the cluster nuclearity, presumably as a cluster hydride was formed; the Ir-Ir near-neighbor distance is close to that of bulk Ir. ${ }^{12}$

(11) van Zon, F. B. M.; Maloney, S. D.; Gates, B. C.; Koningsberger, D. C. To be published.

\section{Discussion}

The results are consistent with the inference that the iridium carbonyl species initially formed from $\left[\mathrm{Ir}_{4}(\mathrm{CO})_{12}\right]$ on the $\mathrm{MgO}$ support were converted in high yield to $\left[\operatorname{Ir}_{6}(\mathrm{CO})_{15}\right]^{2-}$. The evidence includes (1) the infrared spectra of the supported iridium carbonyls, which clearly demonstrate the conversion of the initially formed species but do not give an unequivocal indication of the product, (2) the infrared spectrum of the species extracted from the solid with [PPN] $[\mathrm{Cl}]$, which is consistent with the identification of $\left[\operatorname{Ir}_{6}(\mathrm{CO})_{15}\right]^{2-}$ as the predominant extracted species (which, however, was present with other iridium carbonyl anions and which reacts in the extract solution to give $\left.\left[\operatorname{Ir}(\mathrm{CO})_{4}\right]^{-}\right)$and suggests that this cluster was the predominant organometallic species on the surface, and (3) the EXAFS spectrum of the surface-bound iridium carbonyl.

The EXAFS results provide the strongest evidence; they show that, in the sample prepared from $\left[\mathrm{Ir}_{4}(\mathrm{CO})_{12}\right]$ on $\mathrm{MgO}$ after treatment with $\mathrm{CO}$ at $200^{\circ} \mathrm{C}$, the Ir neighbors included Ir and low- $Z$ scatterers identified as components of carbonyl ligands. The relative contribution of each of these neighboring atoms must be explained to support the identification of the surface species as $\left[\mathrm{Ir}_{6}(\mathrm{CO})_{15}\right]^{2-}$.

All the Ir atoms in crystalline $\left[\mathrm{Ir}_{6}(\mathrm{CO})_{15}\right]^{2-}$ are stereochemically equivalent, with each bonded to two terminal carbonyl ligands and one bridging carbonyl ligand in addition to four Ir atoms. The average Ir-Ir distance is substantially longer $\left(2.773 \AA^{13}\right)$ than those in $\left[\operatorname{Ir}_{4}(\mathrm{CO})_{12}\right]\left(2.69 \AA^{14}\right)$ and $\left[\mathrm{HIr}_{4}(\mathrm{CO})_{11}\right]^{-}\left(2.73 \AA^{15}\right)$.

The EXAFS results for the supported iridium carbonyl match the crystallographic data for $\left[\operatorname{Ir}_{6}(\mathrm{CO})_{15}\right]^{2-13}$ within experimental error: the EXAFS data indicate four Ir neighbors at an average distance of $2.77 \AA$; the agreement is striking.

The EXAFS results are not sufficient to determine fully the carbonyl ligation in the supported cluster, but they can be interpreted satisfactorily on the basis of multiple scattering effects. ${ }^{16}$ The difference between the coordination numbers corresponding to the $\mathrm{Ir}-\mathrm{C}_{\mathrm{t}}(2.5)$ and $\mathrm{I}-\mathrm{O}^{*}(1.3)$ interactions can be understood on this basis, as follows: The positions of the oxygens of the bridging and terminal carbonyl ligands in the crystalline cluster are known. ${ }^{13}$ The distances between the metal and oxygen atoms of the bridging and terminal carbonyl ligands are equivalent; however, the $\mathrm{Ir}-\mathrm{C}-\mathrm{O}_{t}$ angle is $176.2^{\circ}$, whereas the $\mathrm{Ir}-\mathrm{C}-\mathrm{O}_{b}$ angle is $137.8^{\circ} .13$ When the bond angle is greater than approximately $140^{\circ}$, the EXAFS phase shift and amplitude function depend strongly on the positions of the atoms. ${ }^{16}$ The terminal Ir-O interactions in $\left[\operatorname{Ir}_{4}(\mathrm{CO})_{12}\right],{ }^{17}\left[\mathrm{Os}_{3}(\mathrm{CO})_{12}\right],{ }^{18}$ and $\left[\mathrm{H}_{3} \mathrm{Re}_{3}(\mathrm{CO})_{12}\right]^{16}$ illustrate the effect for metal- $\mathrm{C}-\mathrm{O}$ bond angles close to $180^{\circ}$. In contrast, the multiple scattering effect is not significant for the bridging carbonyl oxygen in crystalline $\left[\mathbf{l}_{6}(\mathrm{CO})_{15}\right]^{2-}$, since the $\mathrm{Ir}-\mathrm{C}-\mathrm{O}$ angle is only $137.8^{\circ} .^{13}$

Since the terminal and bridging carbonyl oxygen atoms are located at the same distance from Ir, it is difficult to separate the two contributions and to determine the overall $\mathrm{Ir}-\mathrm{O}^{*}$ coordination number. Consequently, we infer that the discrepancy between the total coordination number determined by the EXAFS data for the $\mathrm{Ir}-\mathrm{O}^{*}$ contribution (1.3) and the expected coordination number (3) is a result of there being two types of carbonyl oxygen contributions at the same distance but experiencing different degrees of multiple scattering that lead to different phase shifts, which may give a negative interference and a low estimate of the overall coordination number.

(12) Wyckoff, R. W. G. Crystal Structures, 2nd ed.; Wiley: New York, 1963; Vol. 1, p 10.

(13) Demartin, F.; Manassero, M.; Sansoni, M.; Garlaschelli, L.; Martinengo, S.; Canziani, F. J. Chem. Soc., Chem. Commun. 1980, 904.

(14) Churchill, M. R.; Hutchinson, J. P. Inorg. Chem. 1978, 17, 3528.

(15) Bau, R.; Chiang, M. Y.; Wei, K.; Garlaschelli, K.; Martinengo, S.; Koetzle, T. F. Inorg. Chem. 1984, $23,4758$.

(16) van Zon, F. B. M.; Kirlin, P. S.; Gates, B. C.; Koningsberger, D. C. J. Phys. Chem. 1989, 93, 2218.

(17) Maloney, S. D. Ph.D. Dissertation, University of Delaware, Newark, DE, 1990.

(18) Duivenvoorden, F. B. M.; Koningsberger, D. C.; Uh, Y. S.; Gates, B. C. J. Am. Chem. Soc. 1986, 108, 6254 . 
TABLE III: Comparison of X-ray Crystallographic Data for $\left[\mathrm{Ir}_{6}(\mathrm{CO})_{13}\right]^{2-}$ and EXAFS Results for the MgO-Supported Sample Prepared from $\left[\mathrm{Ir}_{4}(\mathrm{CO})_{12}\right]$ following Treatment with $\mathrm{CO}$ at $1 \mathrm{~atm}$ and $200^{\circ} \mathrm{C} e$

\begin{tabular}{|c|c|c|c|c|c|}
\hline \multirow[b]{2}{*}{ contribn } & \multicolumn{2}{|c|}{$\begin{array}{l}\text { crystallogr data } \\
\text { for }\left[\mathrm{Ir}_{6}(\mathrm{CO})_{15}\right]^{2-12}\end{array}$} & \multicolumn{3}{|c|}{$\begin{array}{l}\text { EXAFS data for } \\
\text { Ir carbonyl on } \mathrm{MgO}\end{array}$} \\
\hline & $N$ & $R, \AA$ & $\bar{N}$ & $R, \AA$ & $\overline{\Delta \sigma^{2}, \AA^{2}}$ \\
\hline $\begin{array}{l}\mathrm{Ir}-\mathrm{C}_{\mathrm{t}} \\
\mathrm{Ir}-\mathrm{C}_{\mathrm{b}} \\
\mathrm{Ir}-\mathrm{Ir} \\
\mathrm{Ir}-\mathrm{O}^{*}{ }^{*} \\
\mathrm{I} r-\mathrm{O}^{*}{ }_{\mathrm{b}} \\
\mathrm{I} r-\mathrm{O}^{*}\end{array}$ & $\begin{array}{l}2 \\
1 \\
4 \\
2 \\
1\end{array}$ & $\begin{array}{l}1.86 \\
2.04 \\
2.77 \\
3.02 \\
3.02\end{array}$ & $\begin{array}{l}2.5 \\
1.5 \\
4.1\end{array}$ & $\begin{array}{l}1.85 \\
2.13 \\
2.77\end{array}$ & $\begin{array}{r}0.0042 \\
-0.0004 \\
0.0010\end{array}$ \\
\hline
\end{tabular}

\section{SCHEME I: Transformation of Iridium Carbonyls on the MgO} Surface

$$
\begin{aligned}
& {\left[\mathrm{II}_{4}(\mathrm{COO})_{12}\right]+\mathrm{MgO}} \\
& \text { Adsorption } 23^{\circ} \mathrm{C}
\end{aligned}
$$

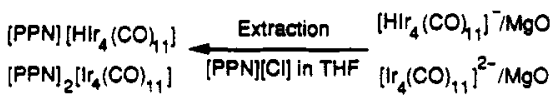

$$
\begin{aligned}
& \text { Extraction } C O \mid \begin{array}{c}
1 \mathrm{~atm} \\
100^{\circ} \mathrm{C}
\end{array} \\
& {[\mathrm{PPN}]_{2}\left[\mathrm{ll}_{8}(\mathrm{CO})_{22}\right] \frac{\text { Extraction }}{[\mathrm{PPN}][\mathrm{CO}] \text { in THF }}\left[\mathrm{ll}_{8}(\mathrm{CO})_{22}\right]^{2} \mathrm{MgO}} \\
& \text { Co } \mid \begin{array}{l}
1 \text { atm } \\
200^{\circ} \mathrm{C}
\end{array} \\
& {[\mathrm{PPN}]_{2}\left[l_{6}(\mathrm{CO})_{15}\right] \frac{\text { Extraction }}{[\mathrm{PPN}][\mathrm{Cl}) \text { in THF }}\left[\mathrm{Ir}_{6}(\mathrm{CO})_{15}\right]^{2-} / \mathrm{MgO}}
\end{aligned}
$$

In summary, the comparison between the EXAFS results for the sample formed from $\left[\mathrm{Ir}_{4}(\mathrm{CO})_{12}\right]$ after treatment in $\mathrm{CO}$ at 200 ${ }^{\circ} \mathrm{C}$ and the crystal structure data for $\left[\mathrm{Ir}_{6}(\mathrm{CO})_{15}\right]^{2-}$ is shown in Table III. There is good agreement in the characterization of the iridium cluster frame; the EXAFS data are not sufficient to determine the carbonyl ligand environment, but the data are consistent with those of the crystalline cluster when interference between the terminal and bridging carbonyl oxygens is considered. We conclude, therefore, that the predominant surface species on $\mathrm{MgO}$ after the treatment in $\mathrm{CO}$ was $\left[\operatorname{Ir}_{6}(\mathrm{CO})_{15}\right]^{2-}$ and that the formation of this cluster anion is one of the few examples of an efficient surface-mediated synthesis. ${ }^{19}$

The transformations of the iridium carbonyls on the $\mathrm{MgO}$ surface are summarized in Scheme I; the "molecular" chemistry represented here as taking place on the basic surface closely parallels the chemistry of iridium carbonyls in basic solutions. ${ }^{5,7}$ Evidence of the formation of $\left[\mathrm{I}_{8}(\mathrm{CO})_{22}\right]^{2-}$ on the surface is presented elsewhere. ${ }^{20}$ This surface chemistry adds to the pattern of reactions of metal carbonyl anions on $\mathrm{MgO}$ that parallels such chemistry in basic solutions. ${ }^{21}$

The hexairidium cluster anion is robust, and when the $\mathrm{MgO}$ supported species was treated in $\mathrm{He}$, and then in $\mathrm{H}_{2}$ at $300^{\circ} \mathrm{C}$ to remove the carbonyl ligands, the metal frame was not substantially restructured. The EXAFS data for the decarbonylated sample are not sufficient to determine the structure, but they are consistent with the inference that the $\mathrm{Ir}_{6}$ frame remained largely intact during the decarbonylation. The resulting surface species, likely a mixture of iridium hydrides, is regarded as a nearly uniform supported metal. The structural uniformity allows a detailed analysis of the EXAFS data to provide structural evidence of the metal-support interface, which is to be reported separately."

(19) Lamb, H. H.; Fung, A. S.; Tooley, P. A.; Puga, J.; Krause, T, R.; Kelley, M. J.: Gates, B. C. J. Am. Chem. Soc. 1989, 11l. 8367

(20) Maloney, S. D.; Kelley, M. J.; Gates, B. C. J. Organomet. Chem., submitted for publication.

(21) Lamb, H. H.; Gates, B. C.; Knözinger, H. Angew. Chem., Int. Ed. Engl. 1988, 27, 1127.
Experimental Methods

Sample Preparation. Samples were prepared under $\mathbf{N}_{2}$ in a Vacuum Atmospheres glovebox and on a Schlenk vacuum line. $\left[\mathrm{Ir}_{4}(\mathrm{CO})_{12}\right]$ (Strem) was used without further purification. Reagent grade hexanes were dried by refluxing over sodium benzophenone ketyl. $\mathbf{N}_{2}$ with a purity of $99.999 \%$ was purchased from Matheson and passed through beds of $\mathrm{Cu}_{2} \mathrm{O}$ and molecular sieve to remove traces of $\mathrm{O}_{2}$ and moisture. $\mathrm{CO}$ was purchased from Matheson (UHP grade) and passed through a bed of activated carbon heated to a temperature $>200^{\circ} \mathrm{C}$ to remove traces of iron carbonyl contaminants and through a bed of molecular sieve particles to remove moisture.

Partially dehydroxylated $\mathrm{MgO}$ powder was prepared as the powder $\mathrm{MgO}$ (MCB) in flowing $\mathrm{O}_{2}$ was heated to $400^{\circ} \mathrm{C}$ and then held at that temperature for $2 \mathrm{~h}$. The $\mathrm{MgO}$ was then placed under vacuum (ca. $10^{-3}$ Torr), held at $400^{\circ} \mathrm{C}$ for $14 \mathrm{~h}$, and cooled under vacuum to room temperature and unloaded in the glovebox. The sample had a surface area of $75 \mathrm{~m}^{2} / \mathrm{g}$, determined by $\mathrm{N}_{2}$ adsorption.

The $\mathrm{MgO}$-supported iridium carbonyl was prepared by slurrying $\left[\mathrm{Ir}_{4}(\mathrm{CO})_{12}\right](0.029 \mathrm{~g})$ in freshly distilled hexanes $(50 \mathrm{~mL})$ in a Schlenk flask under a $\mathrm{N}_{2}$ blanket. This calcined $\mathrm{MgO}(2.0 \mathrm{~g})$ was then added to the slurry. The mixture was stirred under $\mathrm{N}_{2}$ for $4 \mathrm{~h}$ at room temperature then dried by evacuation for $14 \mathrm{~h}$ at room temperature.

$\left[\mathrm{Ir}_{6}(\mathrm{CO})_{15}\right]^{2-}$ was prepared by the method of Stevens et al. ${ }^{?}$ as $\left[\mathrm{Ir}_{4}(\mathrm{CO})_{12}\right]$ was slurried with THF under $\mathrm{CO}$, and several pieces of $\mathrm{Na}$ were added. The mixture was stirred for several hours, and the solution spectrum monitored by infrared spectroscopy.

Infrared Spectroscopy. Transmission infrared spectra of liquids were collected with a Nicolet 7199 spectrometer. The spectra of powder samples were collected with the instrument operated in the DRIFTS (diffuse reflection infrared Fourier transform spectroscopy) mode; the cell, part of a flow system, was equipped with a sapphire window. Sample handling was done in the drybox.

The infrared experiments with the solid were performed after connection of the cell to a gas manifold allowing flow of $\mathrm{He}, \mathrm{N}_{2}$, $\mathrm{CO}$, and $\mathrm{H}_{2}$. After removal of the residual air from the flow system, the flow to the cell was begun; flow rates were 20-30 $\mathrm{mL} / \mathrm{min}$. The sample was typically heated to a set temperature, allowed to reach steady state in $1 / 2 \mathrm{~h}$, and then scanned 32 or more times; the signal was averaged. The sample scans were ratioed to the signal from dried $\mathrm{KBr}$ (512 scans) and the $\mathrm{Ku}$ belka-Munk function calculated.

Extraction of Metal Carbonyls from the MgO Surface. Surface-bound iridium carbonyls were extracted from $\mathrm{MgO}$ as the solid sample in the drybox was brought in contact with a solution of bis(triphenylphosphine)iminium chloride ([PPN][Cl]) in freshly distilled tetrahydrofuran (THF). The liquid was transferred by pipet into the solution infrared cell; the solution was usually concentrated by removal of excess solvent by evacuation in a separate flask prior to transfer into the infrared cell. The sample was sealed in the cell, removed from the drybox, and scanned quickly. The infrared data for the sample were ratioed to the background atmosphere in the spectrometer, and the infrared bands for THF were subtracted from the spectrum.

X-ray Absorption Spectroscopy. Sample Preparation and Data Collection. The samples, some having undergone treatments in gas atmospheres, were pressed into wafers. The $\mathrm{MgO}$-supported sample prepared from $\left[\operatorname{Ir}_{4}(\mathrm{CO})_{12}\right]$ as described above was loaded, under $\mathrm{N}_{2}$, into a tubular stainless-steel reactor and treated under flowing $\mathrm{CO}$ at $1 \mathrm{~atm}$. With a flow rate of about $30 \mathrm{~mL} / \mathrm{min}$, the sample was heated to $200^{\circ} \mathrm{C}$ at a rate of $5^{\circ} \mathrm{C} / \mathrm{min}$ and then held at $200^{\circ} \mathrm{C}$ for $8 \mathrm{~h}$; the sample was cooled to room temperature under $\mathrm{CO}$ flow. At room temperature, the reactor was flushed with $\mathrm{He}$ for $3 \mathrm{~min}$, and the sample was unloaded into a sample vial inside the drybox. The sample was placed inside three layers of glass vials, each individually sealed with parafilm, the vial cap, and electrical tape. All these steps were carried out at the University of Delaware.

The packaging precautions were taken to allow transport of the sample, without air contamination, to the Synchrotron Light 
TABLE IV: Structural Parameters for the Reference Compounds and the EXAFS Parameters Reported for the Preparation of the Reference Files ${ }^{a}$

\begin{tabular}{|c|c|c|c|c|c|c|c|c|}
\hline \multirow[b]{2}{*}{$\begin{array}{l}\text { reference } \\
\text { compd }\end{array}$} & \multirow[b]{2}{*}{ shell } & \multirow[b]{2}{*}{$N$} & \multirow[b]{2}{*}{$R, \AA$} & \multirow[b]{2}{*}{ ref } & \multicolumn{4}{|c|}{ Fourier transform } \\
\hline & & & & & $n$ & $k \underset{\AA^{-1}}{\text { range, }}$ & $R$ range, & ref \\
\hline $\begin{array}{l}\mathrm{Pt} \text { foil } \\
\mathrm{Ir}_{4}(\mathrm{CO})_{12} \\
\mathrm{Ir}_{4}(\mathrm{CO})_{12}\end{array}$ & $\begin{array}{l}\mathrm{Pt}-\mathrm{Pt} \\
\mathrm{Ir}-\mathrm{C} \\
\mathrm{Ir}-\mathrm{O}^{*}\end{array}$ & $\begin{array}{r}12 \\
3 \\
3\end{array}$ & $\begin{array}{l}2.77 \\
1.87 \\
3.01\end{array}$ & $\begin{array}{r}9 \\
14 \\
14\end{array}$ & $\begin{array}{l}3 \\
3 \\
3\end{array}$ & $\begin{array}{l}1.95-19.97 \\
2.80-16.45 \\
2.80-16.45\end{array}$ & $\begin{array}{l}1.90-3.02 \\
1.06-1.98 \\
1.98-3.30\end{array}$ & $\begin{array}{l}21 \\
21 \\
21\end{array}$ \\
\hline
\end{tabular}

- Notation: $n$, power of $k$ used in weighting of Fourier transform; $k$ range, limits of forward Fourier transformation; $R$ range, limits of shell isolation [ $\mathrm{Ir}-\mathrm{Ir}$ contribution $(N=3, R=2.69 \AA)$ previously subtracted].

Source in Daresbury, U.K., where it was loaded into an EXAFS cell inside a drybox purged with $\mathrm{N}_{2}$. The loaded EXAFS cell was purged with $\mathrm{He}$ for $3 \mathrm{~min}$ at room temperature and closed under a positive pressure of $\mathrm{He}$.

A fraction of the sample was returned to Delaware and checked with infrared spectroscopy to confirm its stability during the handling. The spectrum showed no measurable change.

The EXAFS data were collected at X-ray beamline 9.2 with $\mathrm{Si}(220)$ crystals in the monochromator. The sample was scanned at the Ir $\mathrm{L}_{\text {[II }}$ edge $(11215 \mathrm{eV})$, and the data from three scans were averaged. The data were collected after the monochromator had been detuned by $50 \%$ to minimize the effects of higher harmonics present in the X-ray beam. The sample contained $0.96 \mathrm{wt} \% \mathrm{Ir}$, as estimated from the step height in the $\mathrm{X}$-ray absorption spectrum.

Reference Materials. Pt foil and $\left[\mathrm{Ir}_{4}(\mathrm{CO})_{12}\right]$ were used as references for analysis of the EXAFS data. The reference data were collected at beamline 9.2 at Daresbury. The Ir-Ir contributions were characterized with an experimentally determined reference file obtained from EXAFS data for the Pt foil. The interactions between the Ir atoms and the terminal and bridging carbon atoms, Ir $-C_{t}$ and $I r-C_{b}$, respectively, were analyzed with the reference file characterizing the $\mathrm{Ir}-\mathrm{C}$ interaction in $\left[\operatorname{Ir}_{4}(\mathrm{CO})_{12}\right]$. The interactions between $\mathrm{Ir}$ and $\mathrm{O}^{*}$ were also analyzed with a reference file obtained with $\left[\operatorname{Ir}_{4}(\mathrm{CO})_{12}\right]$. The details of the generation of these reference files are described elsewhere. ${ }^{22}$ The structural parameters of the reference materials and the EXAFS parameters reported for the preparation of the reference files are shown in Table IV.

Acknowledgment. We thank Professor W. L. Gladfelter for helpful comments about the infrared spectra and ion pairing and for providing unpublished infrared spectra. This research was supported by the National Science Foundation (CTS-8910633 and CTS-9012910) in the U.S.A., by the NWO in the Netherlands, and by a NATO travel grant.

(22) van Zon, F. B. M. Ph.D. Thesis, Eindhoven University of Technology, The Netherlands, 1988

\title{
Cation Location in La,Na-Y Zeolites by Two-Dimensional ${ }^{23} \mathrm{Na}$ Nutation NMR
}

\author{
Chiung-Fang Lin and Kuei-Jung Cha** \\ Department of Chemistry, Tsinghua University, Hsinchu, Taiwan, Republic of China
} (Received: December 3, 1990)

\begin{abstract}
The variation of the cation distribution with the lanthanum-exchanged level in hydrated $\mathrm{La}, \mathrm{Na}-\mathrm{Y}$ zeolites was clearly monitored by two dimensional nutation sodium-23 NMR, in which the chemical shift and the quadrupole interaction could be separated. From a comparison of ${ }^{23} \mathrm{Na}$ NMR at different hydrated states and temperatures it is concluded that the mobility of water molecules and sodium ions can be reduced by decreasing sample temperature and the migration of lanthanum ions from supercages to small cages causes the redistribution of sodium ions after dehydration at $350^{\circ} \mathrm{C}$.
\end{abstract}

\section{Introduction}

The acidity and thermal stability of synthetic $\mathrm{Na}-\mathrm{Y}$ zeolite can be dramatically improved by ion exchange with lanthanum ions, and the amount of improvement is controlled by the degree of exchange and therefore the location of the cations. ${ }^{1,2}$ The structural characteristics and the catalytic application of $\mathrm{La}, \mathrm{Na}-\mathrm{Y}$ zeolites have been extensively investigated; most of the published structural studies were done on a lanthanum-exchanged $\mathrm{Y}$ zeolite under different heat treatments. ${ }^{3-9}$ Few studies were found on

(1) Ikemoto, M.; Tsutsumi, K.; Takahashi, H. Bull. Chem. Soc. Jpn. 1972. 45, 1330 .

(2) Jacobs, P. A. Carboniogenic Activity of Zeolite; Elsevier: Amsterdam. 1977; p 125

(3) Costenoble, M. L.: Mortier, W. J.; Uytterhoeven, J. B. J. Chem. Soc. Faraday Trans. I 1978, 74, 466; 1976, 72, 1877.

(4) Bennett, J. M.; Smith, J. V. Mater. Res. Bull. 1968, 3, 865; 1969, 4, 7; $1969,4,343$

(5) Cheetham, A. K.; Eddy, M. M.; Thomas, J. M. J. Chem. Soc., Chem. Commun. 1984, 1337

(6) Jacobs, P. A.; Uytterhoeven, J. B. J. Chem. Soc., Faraday Trans. 1 $1973,69,373$

(7) Scherzer, J.; Bass, J. L.; Hunter, F. D. J. Phys. Chem. 1975, 79, 1194

(8) Roessner, F.; Steinberg, K. H.; Winkler, H. Zeolites 1987, 7, 47 the effect of the degree of cation exchange on the cation distribution in Y zeolites. ${ }^{10-12}$ The determination of the cation distribution has involved a number of techniques, e.g., X-ray and neutron diffractions, ${ }^{3-5}$ infrared, ${ }^{6-8}$ and NMR. ${ }^{9-13}$ With use of diffraction methods, the stationary cations can be located, and about half of cations can of ten be located for hydrated samples by X-ray diffraction. With the IR method, the vibrational modes of framework and the adsorbed molecules are usually investigated; however, only limited information was obtained for the distribution of cations in zeolites. Our previous ${ }^{29} \mathrm{Si}$ NMR study 9.10 showed that the variation of the cation location and occupancy at different sites led to the change of the electric field on framework silicon atoms around cation sites and hence the change of corresponding

(9) Chao, K. J.; Chern, J. Y. J. Phys. Chem. 1989, 93, 1401.

(10) Chao, K. J.; Chern, J. Y.; Chen, S. H.; Shy, D. S. J. Chem. Soc. Faraday Trans. 1990, 86, 3167

(11) Welsh, L. B.; Lambert, S. L. In Characterization and Catalyst Development. ACS Symp. Ser. 1989, 411, 262-273.

(12) Hayashi, S.; Hayamizn, K.; Yamamoto, O. Bull. Chem. Soc. Jpn. 1987, 60, 105

(13) Welsh, L. B.; Lambert, S. L. Perspectives in Molecular Sieve Science. ACS Symp. Ser. 1988, 368, 33-47. 